\title{
USING ICT AND SERVICE LEARNING IN RURAL SENEGAL PROJECT FUNDED BY USAID/HED
}

\author{
Vishnu Vinekar, Fairfield University, vvinekar@fairfield.edu \\ Elizabeth Langran, Marymount University, elizabeth.langran@marymount.edu \\ Winston Tellis, Fairfield University, winston@fairfield.edu
}

\begin{abstract}
In 2010, Fairfield University received a three-year grant from the United States Agency for International Development (USAID), through Higher Education for Development (HED), to support a university service-learning program to deliver educational material on health-related topics to middle school students in Bambey, Senegal, a rural area, 60 miles east of the capital, Dakar. Fairfield University must work with the selected partner, Université de Bambey, which has four rural campuses, about 20 miles apart, connected by both paved and dirt roads. Resources are scarce, as is a consistent electricity and water supply. However, the faculty is dedicated and competent, and the students are vibrant, intelligent, and hard working. The various courses of study are distributed across the campuses, unlike the variety on a single campus in the United States. Each Université de Bambey campus might have just two or three majors of study. The USAID/HED grant specifies that Service- Learning must be used to deliver the training, and the use of computer technology is essential. The project will begin with pretesting of the professors and students, followed by testing at the end of the project, to assess the success of the project.
\end{abstract}

Keywords: Service Learning, Digital Story Telling, USAID, rural education

\section{INTRODUCTION}

The digital divide refers to the gap between people who have access to information and communication technology and those who do not [6]. However, some scholars believe that access is not enough; people also need the skills to be able to use ICT [1] and the ability to derive benefits from it [8].

Digital technologies are powerful accelerators of social and economic change [5],[9], and the digital divide may be one of the more significant issues facing impoverished countries [5]. The digital divide is associated with inequality more than equality [7]. The digital divide has been shown to negatively affect several important life outcomes, including access to opportunity. One important negative impact of the digital divide is lower access to healthcare information, which in turn decreases self-confidence and trust, and may delay much-needed medical intervention [4].

The global digital divide is severe, and it is growing, not reducing [6]. Only 22 percent of Asians and 11 per cent of Africans have access to the Internet [5]. In addition, while cultural factors such as uncertainty avoidance played a significant role in the digital divide in the 1990s, in the 2000s, GDP per capita is the more significant predictor. However, literacy rate is more significantly associated with predicted future ICT adoption across countries [6]. At the regional level, while income gap is correlated with the digital gap, regional policy seems to have an effect on the digital divide. The rural-versus-urban dimension seems to have less of an effect on the digital divide [10].

The Digital Divide Framework [8] posits that the adoption process occurs in three stages: First, individuals get access to IT. Second, they develop usage capabilities. Third, they achieve outcomes, including skills and knowledge. Therefore, the digital divide can be characterized as gaps in access, usage and outcomes. These three stages are measured at the individual level through home and school computing environments, Computer Self-Efficacy (CSE), and knowledge and skills, respectively. Wei et al [8] find that home computer usage for leisure and studies explains 8.5\% of the variance in Computer Self-Efficacy (CSE). The school computing environment accounted for an additional $28-20 \%$ of variance in CSE for students without and with home computers. Female students have lower 
usage than male students, and home computing environments explain more of the variance in CSE for female students. In turn, Computer Self-Efficacy (CSE) explains 14-20\% of the variance in knowledge outcomes and 12$17 \%$ of the variance in skill outcome.

\section{The Project}

The ultimate goal of this project is to reduce the digital divide while improving community health in the rural areas of Senegal. To achieve this, Fairfield University will partner with a new Senegalese University, Université de Bambey (UB). The objective is to set up a service-learning program at UB that will harness the strengths of UB's students, faculty, and administration. Every semester, UB students will work on service learning projects with various community partners, including middle schools, women's associations, community leaders and labor associations. These service-learning projects will involve students working with these community partners to spread knowledge of Information and Communication Technologies (ICT) as well as knowledge of community health issues. With a self-sustaining service learning program set up at UB, Fairfield University will no longer be needed. Every semester, UB students will work with different community partners, resulting in the spread of ICT knowledge and community health throughout rural Senegal.

Université de Bambey has four rural campuses, about 20 miles apart, connected by a single paved road. Resources are scarce, as is electricity and water supply. However, the faculty is dedicated and competent, and the students are vibrant, intelligent, and hard working. The various courses of study are distributed on the campuses, unlike the variety on a single campus in the United States. Each campus might have just two or three majors of study. The grant specifies that Service Learning must be used to deliver the training and the use of computer technology is essential. The project will begin with pretesting of the students, faculty and administration of UB as well as local community partners. Comparative testing at the end of the project will assess the success of the project.

This project will integrate service learning, health education for middle school students, and teacher training in educational technology for the Université de Bambey (UB), Senegal. It will leverage new learning technologies as appropriate for the local environment for teaching health education topics. Teachers will become familiar with the pedagogy of using technology to teach content. While the first content area to be taught with the technology will be health education, the pedagogy can be applied to other content areas as well.

Service learning is a pedagogical approach that links academic study and community-based service so that each is strengthened and both are transformed. Critical (i.e., conceptual/academic, civic/social, and personal/spiritual) reflection is an essential component of service learning, as is the development of partnerships with the community that are based in mutuality, reciprocity, and cooperative education for the common good.

\section{Partnership Design \& Implementation Plan}

Over the three-year plan for this project, we will first conduct a needs assessment, in partnership with UB. Together, we will develop a curriculum after consultation with the advisory board of the pilot school. The baseline data collected at this stage will inform our decisions for the following years. In the second year (fall 2011-summer 2012), we will use a "train the trainer" approach to work with the UB faculty in both service learning and the use of technology in health education delivery. The trained UB faculty will train the students at UB, who will in turn work with the teachers in the local schools. Service learning will be a major focus during year two, with appropriate onsite guidance by a Fairfield University faculty in residence at UB. Assessment will continue throughout the plan. Full-scale implementation will begin in the third year (fall 2012), with completely trained UB faculty guiding the process for the new participants. The budget is adequate to ensure a successful project implementation and completion.

Mr. Cheikh Mbacke Sene, Secretary General of UB, told us that Senegal needs health education especially in topics such as malaria, diabetes, water and food safety, and sanitation. The content of the health education curricula was designed by a group of faculty from the Health Sciences at the Diourbel campus. This group is actively engaged in 
service to the community, often with students who are in the Health Sciences courses. They developed five themes that are important to the rural population of that region. The topics for further development were:

1. Reproductive health

2. Malaria prevention at community groups and institutions

3. Hygiene in schools and community groups

4. Oral Hygiene in elementary schools, middle and high schools, athletics, women's groups

5. Smoking in middle schools and high schools, and the community

We will address the sustainability of this initiative by including information literacy - instruction on how to research health issues and to update current materials—within a pedagogical framework.

Training in educational technology pedagogy will be an important part of this project. The integration of technology and content into a classroom creates opportunities for rich educational experiences that are inquiry-oriented, learnercentered, and multisensory while accommodating varying learning styles. Available and appropriate technology will be used as a tool to teach the content of health education, thus achieving both the health education goals, professional development, and experience for faculty and students in effective teaching methods using digital technologies. Educational technology pedagogy applied to the health education curricula may be extended to teach other content areas (math, science, language, etc.) in the future.

\section{Performance objectives to be achieved in a three-year period}

1. A service-learning program will be established at UB with a train-the-trainer approach. French-language written and video materials to support service-learning curricula will be developed in consultation with UB faculty and administration.

2. Fairfield University's own service learning program's international student experiences will include West Africa; Graduate students will begin to participate in international service learning. A new graduate course centering on international issues of digital equity and global collaboration will be developed to support this service learning experience.

3. Middle school teachers in target Senegalese schools will have consistent professional development in using technology to deliver health education. French-language curriculum materials for using technology to deliver health education and basic information literacy skills will be developed in consultation with middle school teachers, UB faculty and students, and subject matter experts, including Fairfield University School of Nursing Faculty, and Fairfield University alumni with experience in Senegal.

4. An online collaborative environment has been developed for the partner institutions to collaborate, communicate, and access materials related to the partnership and community service programs. In addition, Information Technology students at the campuses will develop a website for the project.

5. UB faculty will receive professional development from Fairfield University's Center for Academic Excellence “Technology, Pedagogy, and Course Redesign” conference. During the UB faculty's visit to Fairfield University, they will have opportunities to participate in service learning sites near Fairfield University.

6. If mutually acceptable to administrations of both institutions, a Memo of Understanding between the two institutions will allow for sustained faculty and student exchanges in the future beyond the three-year grant period.

\section{Joint planning with UB and the Ministry of Higher Education in Senegal}

Our planning discussions with Mr. Sene (Secretary General of UB and contact for the Ministry of Higher Education) addressed the needs, infrastructure, and resources in the area, as well as our university's previous experiences in similar communities. We jointly devised a work plan that is designed to meet the needs of local communities. To ensure community participation, we encourage the formation of advisory boards to allow the various stakeholders to have voice in the process. We previously did this with an elementary school, Sacoura Badiane School in Dakar, and we are familiar with some of the context and benefits to this approach. 
The implementation plan will start with faculty from Fairfield University traveling to Senegal to meet with UB faculty and the Ministry of Higher Education to collaboratively develop a community health service-learning program using a train-the-trainer approach. Using in-person meetings and an online collaboration portal, stakeholders from UB, the Ministry of Higher Education, Fairfield University, and other partners will collaborate in all stages of the project development.

\section{Feasibility of the work plan to achieve outcomes on time}

We have developed the work plan mindful of the schedule feasibility, by dividing the project into distinct phases and using pilot segments to minimize risks. The implementation will occur with a phased pilot approach. In the first year, after conducting a needs assessment, we developed health education and ICT materials in French and piloted them at the target middle school, Sacoura Badiane. The learning outcomes from the pilot will determine the feasibility of the approach and the appropriateness of the materials; changes will be made as needed. Work will then begin on the service-learning training materials. In the second year, we deliver our first "training of trainers" session for UB faculty. Then, we will use the rapid prototyping approach to refine service-learning materials. Dr. Winston Tellis from Fairfield University will be in Senegal during the 2012 Spring semester to help with the success of this phase. Following this, UB students will receive service learning training, and participate in teacher partnerships in a small number of local schools. Students from the Graduate School of Education \& Allied professions at Fairfield University will be present to assist in the training. During this year, we will also conduct a mid-project assessment to identify and correct any risks.

In the third year, we will move to full-scale implementation of the service-learning project at UB. The activities from the phased pilots in the earlier two years would have mitigated most of the risks, but Fairfield University students and faculty will be in Senegal for service learning trips to support and monitor implementation.

\section{Development and Implementation of Community Service Learning Program}

Prior to development of materials and implementation of the community service-learning program, a thorough needs assessment must be completed. An experienced team of faculty from Fairfield University traveled to UB to conduct a needs assessment in the first stage of the partnership. Data was collected from interviews with stakeholders and subject matter experts and observations of university and middle school environments. The needs assessment consisted of the following:

- Assessment of the social, physical, and institutional environments

- Analysis of identified needs (methods and materials to meet needs will be considered)

- Statement of proposed action in the form of a goal statement, which will be used to develop instructional objectives

The needs assessment process will inform the development of the curriculum and structure of the community service learning program. The guiding principles for community service learning that were developed at Fairfield University may provide some initial framework if appropriate for the UB setting. The service learning program will be developed in phases, working with a small number of students at first, and by the end of year 3 , expanding to the full target population.

\section{Annual Work plan (See Appendix)}

Prior to launching the service learning program, the content that the students are expected to be trained to use (health and ICT modules for use in the middle schools) must be developed and piloted. Fairfield University has an existing relationship with an elementary school in Dakar (Sacoura Badiane) that will serve as a pilot site for the health and ICT modules; this plan has been approved by Mr. Sene. A five-step procedure for deploying eLearning environments [2] will provide the framework for implementation for this pilot phase and we have begun this procedure with Sacoura Badiane: 
1. Assess objectives and constraints. The Principal, Mr. N'Diaye convened a group of 12 teachers, 4 parents, 1 businessperson, and the President of the Management Committee. They assessed the status of the students' computer awareness, and the school's infrastructure. Based on their assessment, they developed a vision for this project, its objectives, and the obstacles they might encounter. Seven activities comprise the first step that must be completed largely by the local advisory board with all constituencies and stakeholders contributing: Activity 1: Define the vision; Activity 2: Define Educational Objectives; Activity 3: Assess Existing Technology and Education Environment; Activity 4: Assess Energy and Geographic Constraints; Activity 5: Assess Training Needs and Available Method; Activity 6: Assess Costs, Benefits, and Feasibility; Activity 7: Define Success Metrics and Evaluation Process

2. Specify a solution based on assessment. Baseline data is used to determine the precise areas of deficiency, and then to design the teacher training and the student lesson plans accordingly. In addition to the educational material, access to the Internet and the related costs are evaluated.

3. Pilot the solution to be deployed. At least one faculty member or administrator from UB should be present for the pilot phase at the Dakar school to observe and learn, however that was infeasible due to local conditions. Then, in consultation with UB faculty member(s) and subject matter experts (Nursing School faculty at Fairfield University, Fairfield University alumni with health-education experience in Senegal), and using data from the needs assessment conducted in the first phase of year one, the health/ICT modules will be published for use in training the Sacoura Badiane teachers. Data will be collected and analyzed.

4. Finalize the solution based on the results of the pilot. The results of the pilot project will inform the process for the expansion of the project to the other middle schools in the UB region. The expanded project would be modified for each school or region of schools to account for important local characteristics and requirements. Each area would form its own advisory board, develop its own plan, identify the teachers to be trained, and align resources.

5. Deploy the solution on a broad scale. With each school or region's plan developed by the respective Advisory Boards, the expansion would have a more reasonable chance of success.

\section{Monitoring, Reporting, and Evaluation Plan}

\section{Method for collecting baseline data}

Initial baseline assessment will be conducted through a survey of current university teaching techniques and curriculum offerings. We will survey:

\section{CONCLUSIONS}

We have described a process by which Information Systems and education professors might share their expertise and experience with colleagues in areas of the world that are deprived of resources and training. Using the resources of the US government, the authors were able to consult with the local community in Senegal, to determine their education needs. Their needs were molded into the call for proposals issued by Higher Education for Development (a division of the American Council on Education) on behalf of the United States Agency for International Development. The selection of this proposal from among the competing proposals indicated that seeking to serve the local population by consulting with them for advice was an important factor. In keeping with academic process, the authors have conducted a pretest of all the constituents in the project. As each phase of the project is completed, post testing will be conducted to assess the effect of the project on the target population, so that future projects might be informed by the results. 
Volume XII, No. 1, pp. 465-473, 2011

Table 1: Data collection measures

\begin{tabular}{|c|c|}
\hline Baseline data & $\begin{array}{l}\text { Comparison (with appropriate modifications for the } \\
\text { Senegalese/Community College / Middle School context) }\end{array}$ \\
\hline 1. UB's pedagogical techniques & $\begin{array}{l}\text { Fairfield University’s Center for Academic Excellence's } \\
\text { 'best practice' recommendations }\end{array}$ \\
\hline 2. UB's service learning offerings & $\begin{array}{l}\text { Fairfield University’s Office of Service Learning's 'best } \\
\text { practice' recommendations }\end{array}$ \\
\hline 3. UB's use of ICT in pedagogy & $\begin{array}{l}\text { Fairfield University's Educational Technology department's } \\
\text { 'best practice' recommendations }\end{array}$ \\
\hline $\begin{array}{l}\text { 4. UB faculty and student's Technology } \\
\text { Acceptance, including performance } \\
\text { expectancy, effort expectancy, computer } \\
\text { self-efficacy and computer anxiety }\end{array}$ & $\begin{array}{l}\text { Validated, reliable scales on computer self-efficacy and } \\
\text { computer anxiety, performance expectancy, and effort } \\
\text { expectancy and other constructs from prior research on } \\
\text { technology acceptance }\end{array}$ \\
\hline 5. Middle schools’ pedagogical techniques & $\begin{array}{l}\text { Fairfield University’s Center for Academic Excellence's } \\
\text { 'best practice' recommendations }\end{array}$ \\
\hline $\begin{array}{l}\text { 6.Middle schools' curricula in health } \\
\text { related topics (including nutrition, } \\
\text { sanitation, and food safety) as well as any } \\
\text { ICT curricula }\end{array}$ & $\begin{array}{l}\text { Current recommendations from the International, National } \\
\text { and Local organizations that study epidemiology, health and } \\
\text { ICT in the region, as well as recommendations from } \\
\text { Fairfield University’s Nursing School and Information } \\
\text { Systems department recommendations }\end{array}$ \\
\hline 7. Middle school's use of ICT in pedagogy & $\begin{array}{l}\text { Fairfield University's Educational Technology department's } \\
\text { 'best practice' recommendations }\end{array}$ \\
\hline \begin{tabular}{|l|} 
8. Middle School's faculty and student's \\
Technology Acceptance, including computer \\
self-efficacy and computer anxiety, \\
performance expectancy, effort expectancy,
\end{tabular} & $\begin{array}{l}\text { Validated, reliable scales on computer self-efficacy and } \\
\text { computer anxiety, performance expectancy, and effort } \\
\text { expectancy and other constructs from prior research on } \\
\text { technology acceptance }\end{array}$ \\
\hline
\end{tabular}

\section{REFERENCES}

1. Bélanger, France (2009) The Impact of the Digital Divide On E-Government Use. Communications of the ACM, Vol. 52 Issue 4, p132-135

2. eLearning for the 21st Century, 2008, http://www.intel.com/worldahead

3. Ferro, Enrico; Helbig, Natalie C.; Gil-Garcia, J. Ramon (2011) The role of IT literacy in defining digital divide policy needs. Government Information Quarterly, Vol. 28 Issue 1, p3-10.

4. Geana, Mugur V.; Greiner, K. Allen (2011) Health information and the digital divide. Journal of Management \& Marketing in Healthcare, May2011, Vol. 4 Issue 2, p108-112

5. Graham, Mark (2011) Time machines and virtual portals. Progress in Development Studies, Vol. 11 Issue 3, p211-227

6. Huang, Chun-Yao; Chen, Hau-Ning. (2010) Global Digital Divide: A Dynamic Analysis Based on the Bass Model. Journal of Public Policy \& Marketing, Vol. 29 Issue 2, p248-264

7. James, Jeffrey (2011) Are Changes in the Digital Divide Consistent with Global Equality or Inequality? Information Society, Vol. 27 Issue 2, p121-128

8. Kwok-Kee Wei; Hock-Hai Teo; Hock Chuan Chan; Tan, Bernard C. Y. (2011) Conceptualizing and Testing a Social Cognitive Model of the Digital Divide. Information Systems Research, Vol. 22 Issue 1, p170-187

9. Lengsfeld, Jörn H. B. (2011) An Econometric Analysis of the Sociodemographic Topology of the Digital Divide in Europe. Information Society, Vol. 27 Issue 3, p141-157

10. Vicente, María Rosalía; López, Ana Jesús (2011) Assessing the regional digital divide across the European Union-27. Telecommunications Policy, Vol. 35 Issue 3, p220-237. 
Year 1 of 3

\section{APPENDIX}

\begin{tabular}{|c|c|c|c|}
\hline Timeframe & Planned Activity* & $\begin{array}{l}\text { Responsible } \\
\text { Party }\end{array}$ & $\begin{array}{l}\text { Anticipated Development } \\
\text { Outputs** }\end{array}$ \\
\hline Fall 2010 & $\begin{array}{l}\text { Develop online collaborative } \\
\text { environment (using a website } \\
\text { and/or course management } \\
\text { system) }\end{array}$ & Fairfield & $\begin{array}{l}\text { An online collaborative } \\
\text { environment will be put in place } \\
\text { for document sharing and } \\
\text { communication among partners }\end{array}$ \\
\hline January 2011 & $\begin{array}{l}\text { Conduct needs assessment: } \\
\text { Fairfield University project } \\
\text { faculty travel to Senegal; Meet } \\
\text { with UB faculty \& Ministry of } \\
\text { Education officials }\end{array}$ & Fairfield + UB & $\begin{array}{l}\text { Assessment of the social, } \\
\text { physical, and institutional } \\
\text { environments, analysis of } \\
\text { identified needs, and statement } \\
\text { of proposed action in the form } \\
\text { of a goal statement will be used } \\
\text { to develop instructional } \\
\text { objectives }\end{array}$ \\
\hline May 2011 & Collect baseline data & Fairfield & $\begin{array}{l}\text { Data will be collected on UB } \\
\text { pedagogy, service learning, and } \\
\text { ICT use, and local middle } \\
\text { school pedagogy, health } \\
\text { curricula, and ICT use }\end{array}$ \\
\hline Spring 2011 & $\begin{array}{l}\text { Develop health education } \\
\text { materials in consultation with } \\
\text { UB staff and pilot school in } \\
\text { Dakar }\end{array}$ & Fairfield + UB & $\begin{array}{l}\text { French-language health } \\
\text { education materials }\end{array}$ \\
\hline May 2011 & $\begin{array}{l}\text { Pilot health education materials } \\
\text { and teacher training at Dakar } \\
\text { school; assess learning outcomes } \\
\text { from pilot }\end{array}$ & Fairfield + UB & $\begin{array}{l}\text { Materials use and learning } \\
\text { outcomes from pilot will inform } \\
\text { next implementation in middle } \\
\text { schools }\end{array}$ \\
\hline Fall 2011 & $\begin{array}{l}\text { Develop service-learning } \\
\text { training materials in } \\
\text { collaboration with UB faculty }\end{array}$ & Fairfield + UB & $\begin{array}{l}\text { French-language service- } \\
\text { learning training prototype } \\
\text { materials }\end{array}$ \\
\hline Fall 2011 & $\begin{array}{l}\text { UB faculty travel to Fairfield } \\
\text { University’s annual June } \\
\text { conference on Technology, } \\
\text { Pedagogy, and Course Redesign } \\
\text { and visit Roger Ludlowe Middle } \\
\text { School (town of Fairfield) and } \\
\text { local service-learning sites. }\end{array}$ & UB & $\begin{array}{l}\text { Human capacity building at UB } \\
\text { and Fairfield University; in- } \\
\text { person meetings to inform } \\
\text { project development }\end{array}$ \\
\hline
\end{tabular}


Year 2 of 3

\begin{tabular}{|c|c|c|c|}
\hline Timeframe & Planned Activity* & $\begin{array}{l}\text { Responsible } \\
\text { Party }\end{array}$ & $\begin{array}{l}\text { Anticipated Development } \\
\text { Outputs** }\end{array}$ \\
\hline Spring 2012 & $\begin{array}{l}\text { First semester-long faculty } \\
\text { exchange (Dr. } \\
\text { Winston Tellis from Fairfield } \\
\text { University spends sabbatical at } \\
\text { UB) }\end{array}$ & Fairfield & $\begin{array}{l}\text { Human capacity building at } \\
\text { UB and Fairfield University; } \\
\text { project development and } \\
\text { implementation of "training of } \\
\text { trainers" session }\end{array}$ \\
\hline Spring 2012 & $\begin{array}{l}\text { Deliver first "training of } \\
\text { trainers" session } \\
\text { for UB faculty: rapid } \\
\text { prototyping of materials in } \\
\text { service-learning }\end{array}$ & Fairfield & $\begin{array}{l}\text { French-language service- } \\
\text { learning training materials } \\
\text { fully developed; } \\
\text { Improvements for UB faculty } \\
\text { in knowledge of ICT } \\
\text { pedagogy, increased ICT } \\
\text { acceptance, service-learning } \\
\text { models }\end{array}$ \\
\hline Spring 2012 & $\begin{array}{l}\text { New Graduate School of } \\
\text { Education \& Allied Professions } \\
\text { Fairfield University course } \\
\text { developed to incorporate } \\
\text { international service-learning }\end{array}$ & Fairfield & $\begin{array}{l}\text { Institutional capacity } \\
\text { strengthening at Fairfield } \\
\text { University; new course } \\
\text { development }\end{array}$ \\
\hline Spring 2012 & $\begin{array}{l}\text { Conduct first round of service- } \\
\text { learning experiences for } \\
\text { Fairfield University students to } \\
\text { travel to Senegal to assist in } \\
\text { training UB students and visit } \\
\text { middle schools; UB students } \\
\text { receive service-learning training } \\
\text { and participate in teacher } \\
\text { partnerships in small number of } \\
\text { local schools. }\end{array}$ & Fairfield + UB & $\begin{array}{l}\text { Students from the Graduate } \\
\text { School of Education \& Allied } \\
\text { Professions participate in } \\
\text { international service learning; } \\
\text { Contributions to Senegal's } \\
\text { national health and ICT } \\
\text { development goals; Middle } \\
\text { school teachers in target } \\
\text { Senegalese schools have } \\
\text { professional development in } \\
\text { using technology to deliver } \\
\text { health education. }\end{array}$ \\
\hline May 2012 & $\begin{array}{l}\text { Mid-project assessment - review } \\
\text { of data collected on UB } \\
\text { pedagogy, service learning, and } \\
\text { ICT use, and local middle school } \\
\text { pedagogy, health curricula, and } \\
\text { ICT use; review of quarterly and } \\
\text { bi-annual reports }\end{array}$ & Fairfield + UB & $\begin{array}{l}\text { Assessment will inform } \\
\text { project implementation for } \\
\text { year } 3\end{array}$ \\
\hline June 2012 & $\begin{array}{l}\text { UB faculty travel to Fairfield } \\
\text { University's annual June } \\
\text { conference on Technology, } \\
\text { Pedagogy, and Course Redesign } \\
\text { and visit Roger Ludlowe Middle } \\
\text { School (town of Fairfield) and } \\
\text { local service-learning sites. }\end{array}$ & UB & $\begin{array}{l}\text { Human capacity building at } \\
\text { UB and Fairfield University; } \\
\text { in-person meetings to inform } \\
\text { project development }\end{array}$ \\
\hline
\end{tabular}


Volume XII, No. 1, pp. 465-473, 2011

Year 3 of 3

\begin{tabular}{|l|l|l|l|}
\hline Timeframe & Planned Activity* & $\begin{array}{l}\text { Responsible } \\
\text { Party }\end{array}$ & $\begin{array}{l}\text { Anticipated Development } \\
\text { Outputs** }\end{array}$ \\
\hline Fall 2012 & $\begin{array}{l}\text { Full-scale implementation of } \\
\text { service-learning project at UB }\end{array}$ & Fairfield + UB & $\begin{array}{l}\text { Institutional capacity } \\
\text { strengthening at UB }\end{array}$ \\
\hline Spring 2013 & $\begin{array}{l}\text { Service-learning trips by } \\
\text { Fairfield University students \& } \\
\text { faculty to UB }\end{array}$ & Fairfield + UB & $\begin{array}{l}\text { Human capacity building at } \\
\text { UB and Fairfield University }\end{array}$ \\
\hline Spring 2013 & $\begin{array}{l}\text { UB faculty travel to Fairfield } \\
\text { University's annual June } \\
\text { conference on Technology, } \\
\text { Pedagogy, and Course Redesign } \\
\text { and visit Roger Ludlowe Middle } \\
\text { School (town of Fairfield) and } \\
\text { local service-learning sites. }\end{array}$ & UB & $\begin{array}{l}\text { Human capacity building at } \\
\text { UB and Fairfield University; } \\
\text { in-person meetings to assess } \\
\text { project and sustainability of } \\
\text { partnership }\end{array}$ \\
\hline Summer 2013 & $\begin{array}{l}\text { Signing of Memo of } \\
\text { Understanding to continue } \\
\text { relationship between the two } \\
\text { universities if sought by both } \\
\text { parties }\end{array}$ & Fairfield + UB & $\begin{array}{l}\text { Memorandum of } \\
\text { Understanding }\end{array}$ \\
\hline $\begin{array}{l}\text { Final assessment of project; data } \\
\text { collection on data collected on } \\
\text { UB pedagogy, service learning, } \\
\text { and ICT use, and local middle } \\
\text { school pedagogy, health } \\
\text { curricula, and ICT use; review of } \\
\text { quarterly and bi-annual reports }\end{array}$ & Fairfield + UB & $\begin{array}{l}\text { Final Project Assessment; } \\
\text { determination of model's } \\
\text { ability to be replicated }\end{array}$ \\
\hline
\end{tabular}

